
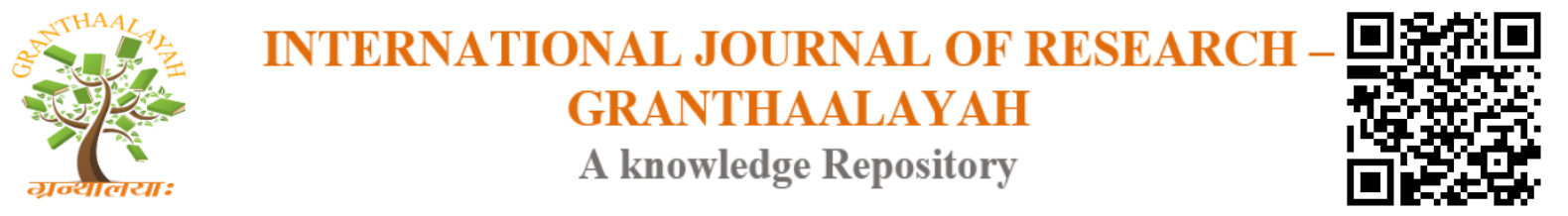

Social

\title{
ECONOMIC IMPROVEMENT OF RURAL BPL HOUSEHOLDS THROUGH SHGS: A STUDY AT AURANGABAD DISTRICT OF MAHARASHTRA
}

\author{
Dr. Shankar Chatterjee *1 \\ ${ }^{* 1}$ Former Professor\& Head (CPME), NIRD \&PR (Govt. of India), Hyderabad-500 030 \\ Telangana, India
}

\begin{abstract}
This study was carried out among the members of self-help groups (SHGs) at Aurangabad District of Maharashtra in the Month of March 2019. Altogether, two SHGs located in two different areas along with the few members of SHGs were contacted to get an idea about the functioning of selfhelp group (SHG) in the district as well as earning (income) of members after joining in the SHG. The SHGs were part of earlier Swarnajayanthi Gram Swarojgar Yojana (SGSY), a selfemployment scheme sponsored under Ministry of Rural Development, Government of India. In view of this few lines about SGSY and its progress are presented here for the benefit of readers. So, the study is based on both primary and secondary data.
\end{abstract}

Keywords: Aurangabad; Income; Self Help Groups (SHGS) And SGSY.

Cite This Article: Dr. Shankar Chatterjee. (2019). "ECONOMIC IMPROVEMENT OF RURAL BPL HOUSEHOLDS THROUGH SHGS: A STUDY AT AURANGABAD DISTRICT OF MAHARASHTRA." International Journal of Research - Granthaalayah, 7(3), 328-334. https://doi.org/10.29121/granthaalayah.v7.i3.2019.978.

\section{Introduction}

To generate self-employment in the rural areas during 1980s and also in 90s different selfemployment programmes were introduced in India. These were Integrated Rural Development Programme (IRDP), Development of Women and Children in Rural Areas (DWCRA), Training of Rural Youth for Self Employment (TRYSEM), Supply of Improved Toolkits for Rural Artisans (SITRA), Million Wells Scheme (MWS) and Ganga Kalyan Yojana (GKY). Later on in 1999, 1st April all these self-employment programmes were merged into one i.e. Swarnajayanthi Gram Swarojgar Yojana (SGSY) and again from June 2011 a new Programme namely National Rural Livelihoods Mission (NRLM, now known as DAY-NRLM, Deendayal Antyodaya YojanaNRLM) was launched in all the rural areas after restructuring SGSY by the Ministry of Rural Development, Government of India. DAY-NRLM has set out with an agenda to cover 7 Crore BPL households, across 600 districts, 6000 blocks, 2.5 lakh Gram Panchayats and 6 lakh villages in the country through self-managed Self Help Groups (SHGs) and federated institutions and 
support them for livelihoods collectives in a period of 8-10 years. In addition, the below poverty line (BPL) households would be facilitated to achieve increased access to their rights, entitlements and public services, diversified risk and better social indicators of empowerment. DAY-NRLM believes in harnessing the innate capabilities of the poor and complements them with capacities (information, knowledge, skills, tools, finance and collectivization) to participate in the growing economy of the country (www.aajeevika.gov.in). For the benefit of researchers and readers progress of SGSY are presented for few years' particularly initial year and fag end of the Yojana. The data were collected from the Annual Report 2009-10 of the Ministry of Rural Development, Government of India so any researcher can use the data according to the requirement.

Table 1: Financial and Physical Progress under SGSY: 1999-2000 and 2005-06 to 2009-10

(Rs. in Crore)

\begin{tabular}{|c|c|c|c|c|c|c|c|}
\hline $\begin{array}{l}\text { Sl. } \\
\text { No. }\end{array}$ & Items & $\begin{array}{l}1999- \\
2000\end{array}$ & $2005-06$ & 2006-07 & 2007-08 & 2008-09 & $\begin{array}{l}2009-10 \\
\text { (Dec. 09) }\end{array}$ \\
\hline $\mathbf{A}$ & Financial Progress & & & & & & \\
\hline 1. & Total Allocation & 1472.33 & 1332.67 & 1466.00 & 2268.82 & 2643.44 & 2688.66 \\
\hline 2. & $\begin{array}{l}\text { Budget Allocation / } \\
\text { Revised Allocation }\end{array}$ & 950.00 & 1000.00 & 1200.00 & 1697.70 & 2350.00 & 2350.00 \\
\hline 3. & Central Allocation & 1105.00 & 1000.00 & 1100.00 & 1702.24 & 2020.00 & 2051.54 \\
\hline 4. & State Allocation & 367.34 & 332.67 & 366.00 & 566.58 & 623.44 & 637.12 \\
\hline \multirow[t]{2}{*}{5.} & Central Releases & 946.76 & 1029.56 & 1188.35 & 1697.70 & 2337.89 & 1632.18 \\
\hline & \%age of Central Releases & 99.66 & 102.96 & 99.03 & 100.00 & 99.48 & 69.45 \\
\hline \multirow[t]{2}{*}{6.} & $\begin{array}{l}\text { Central Releases } \\
\text { (Subsidy to DRDA) }\end{array}$ & 869.55 & 910.27 & 1040.16 & 1540.28 & 1989.60 & 1507.35 \\
\hline & $\begin{array}{l}\% \text { age of Central Releases } \\
\text { (Subsidy to DRDAs) }\end{array}$ & 78.69 & 91.03 & 94.56 & 90.49 & 98.49 & 73.47 \\
\hline \multirow[t]{2}{*}{7.} & State Releases & 261.47 & 315.67 & 338.91 & 475.69 & 542.57 & 354.00 \\
\hline & \%age of State Releases & 71.18 & 94.89 & 92.60 & 83.96 & 87.03 & 55.56 \\
\hline 8. & $\begin{array}{l}\text { Opening Balance as on } \\
\text { 1st April }\end{array}$ & 776.66 & 241.83 & 262.97 & 302.58 & 438.80 & 800.05 \\
\hline 9. & Misc. Receipt & 54.33 & 90.76 & 82.51 & 75.62 & 32.08 & 22.09 \\
\hline 10. & Total Funds Available & 1962.01 & 1558.53 & 1724.55 & 2394.17 & 3003.05 & 2683.49 \\
\hline \multirow[t]{8}{*}{11.} & Total Funds Utilised & 959.86 & 1338.78 & 1424.20 & 1965.97 & 2285.40 & 1548.11 \\
\hline & $\begin{array}{l}\text { Utilization to Funds } \\
\text { Available }(\%)\end{array}$ & 48.92 & 85.90 & 82.58 & 82.12 & 76.10 & 57.69 \\
\hline & $\begin{array}{l}\text { Utilization to Allocation } \\
(\%)\end{array}$ & 65.19 & 100.46 & 97.15 & 86.65 & 86.46 & 57.58 \\
\hline & Utilization of funds & 36.79 & 64.59 & 68.18 & 65.57 & 76.23 & 70.88 \\
\hline & $\begin{array}{l}\text { Utilization of Revolving } \\
\text { fund }\end{array}$ & 5.06 & 11.08 & 9.86 & 9.52 & 10.83 & 13.07 \\
\hline & $\begin{array}{l}\text { Utilization of } \\
\text { Infrastructure Dev. Fund }\end{array}$ & 22.16 & 13.30 & 12.99 & 15.98 & 15.78 & 14.84 \\
\hline & $\begin{array}{l}\text { Utilization of Training / } \\
\text { Skill Dev. Fund }\end{array}$ & 4.65 & 6.31 & 7.26 & 9.76 & 9.42 & 1577.99 \\
\hline & Utilization other fund & 0.79 & 2.16 & 2.15 & 5.48 & 1.93 & 0.18 \\
\hline 10. & Total Credit Target & 3205.00 & 2515.65 & 2869.12 & 3743.55 & 3929.80 & 4443.91 \\
\hline 11. & Total Credit Mobilized & 1056.46 & 1823.16 & 2291.21 & 2760.31 & 3530.07 & 2427.37 \\
\hline & $\begin{array}{lll}\% \text { age } & \text { of } & \text { Credit } \\
\text { Mobilized } & & \\
\end{array}$ & 32.96 & 72.47 & 79.86 & 73.73 & 89.83 & 54.62 \\
\hline
\end{tabular}


DOI: 10.5281/zenodo.2636836

\begin{tabular}{|c|c|c|c|c|c|c|c|}
\hline 12. & Credit Disbursed to SHGs & 187.30 & 1275.41 & 1803.34 & 2090.70 & 2513.38 & 1893.31 \\
\hline 13 & $\begin{array}{l}\text { Credit Disbursed to } \\
\text { Individual Swarojgaris }\end{array}$ & 869.16 & 547.75 & 487.87 & 669.60 & 1016.69 & 534.06 \\
\hline 14. & Total Subsidy Disbursed & 541.69 & 904.83 & 971.05 & 1289.10 & 1742.27 & 1097.47 \\
\hline 15. & $\begin{array}{l}\text { Subsidy } \text { Disbursed } \\
\text { SHGs }\end{array}$ & 124.58 & 671.22 & 771.46 & 990.97 & 1150.94 & 806.43 \\
\hline 16. & $\begin{array}{l}\text { Subsidy Disbursed to } \\
\text { Individual Swarojgaris }\end{array}$ & 417.11 & 233.61 & 199.59 & 298.14 & 591.33 & 291.04 \\
\hline & $\begin{array}{l}\text { Ratio of Investment on } \\
\text { SHGs vs. Individuals }\end{array}$ & 0.24 & 2.49 & 3.75 & 3.18 & 2.28 & 3.27 \\
\hline 17. & Total Investment & 1598.15 & 2727.99 & 3262.27 & 4049.41 & 5272.34 & 3524.85 \\
\hline 18. & $\begin{array}{l}\text { Per Capita Investment (In } \\
\text { Rupees) }\end{array}$ & 17113 & 23699 & 19281 & 28765 & 29932 & 32008 \\
\hline 19. & Credit Subsidy Ratio & 1.95 & 2.01 & 2.36 & 2.14 & 2.03 & 2.21 \\
\hline B. & Physical Progress (No.) & & & & & & \\
\hline 1. & $\begin{array}{l}\text { Self-Help Groups (SHGs) } \\
\text { formed }\end{array}$ & 292426 & 276414 & 246309 & 306688 & 563530 & 278488 \\
\hline 2. & Women SHGs formed & 176263 & 213213 & 176712 & 231670 & 404972 & 214975 \\
\hline 3. & $\%$ age of Women SHGs & 60.28 & 77.14 & 71.74 & 75.54 & 71.86 & 77.19 \\
\hline 4. & $\begin{array}{l}\text { No. of SHGs passed } \\
\text { Grade-I }\end{array}$ & 125402 & 210639 & 222029 & 251163 & 322322 & 273268 \\
\hline 5. & $\begin{array}{l}\text { No. of SHGs passed } \\
\text { Grade-II }\end{array}$ & 74234 & 91920 & 156353 & 116878 & 138641 & 99513 \\
\hline 6. & $\begin{array}{l}\text { SHGs taken up Economic } \\
\text { Activities-Target }\end{array}$ & & 52876 & 77018 & 106036 & 138169 & 155288 \\
\hline 7. & $\begin{array}{l}\text { SHGs taken up Economic } \\
\text { Activities-Achievement }\end{array}$ & 29017 & 80130 & 137931 & 181386 & 114452 & 82063 \\
\hline 8. & $\begin{array}{l}\% \text { age of SHGs Taken up } \\
\text { Eco. Activity to Grade-II }\end{array}$ & 39.09 & 87.17 & 88.22 & 155.19 & 82.55 & 82.46 \\
\hline 9. & $\begin{array}{l}\text { SHGs Swarojgaris } \\
\text { Assisted-Target }\end{array}$ & & 528757 & 770175 & 1060365 & 1381689 & 1552884 \\
\hline 10. & Achievement & 347912 & 873485 & 1472066 & 1154269 & 1470032 & 957769 \\
\hline 11. & $\begin{array}{l}\text { Individual Swarojgaris } \\
\text { Assisted-Target }\end{array}$ & & 330473 & 320906 & 292380 & 380981 & 269598 \\
\hline 12. & Achievement & 585956 & 277631 & 219860 & 253503 & 291392 & 143485 \\
\hline 13. & $\begin{array}{l}\text { Total Swarojgaris } \\
\text { Assisted-Target }\end{array}$ & & 859230 & 1091081 & 1352745 & 1762670 & 1822482 \\
\hline 14. & Achievement & 933868 & 1151116 & 1691926 & 1699295 & 1861875 & 1164898 \\
\hline 15. & $\begin{array}{l}\% \text { age of SHGs } \\
\text { Swarojgaris Assisted }\end{array}$ & 37.25 & 75.88 & 87.01 & 67.93 & 78.95 & 82.22 \\
\hline 16. & SC Swarojgaris Assisted & 278938 & 383124 & 600364 & 561052 & 601299 & 409974 \\
\hline 17. & ST Swarojgaris Assisted & 134944 & 165407 & 241291 & 251783 & 274530 & 177981 \\
\hline 18. & $\begin{array}{l}\text { Total SC/ST Swarojgaris } \\
\text { Assisted }\end{array}$ & 413882 & 548531 & 841655 & 812835 & 875829 & 587955 \\
\hline 19. & $\begin{array}{l}\text { Minorities (Swarojgaris) } \\
\text { Assisted }\end{array}$ & & -- & 60494 & 142399 & 275121 & 129714 \\
\hline 20. & $\begin{array}{ll}\text { Women } & \text { Swarojgaris } \\
\text { Assisted } & \end{array}$ & 416690 & 662764 & 1247132 & 1083905 & 1206513 & 784725 \\
\hline
\end{tabular}


DOI: 10.5281/zenodo.2636836

\begin{tabular}{|l|l|l|l|l|l|l|l|}
\hline 21. & $\begin{array}{l}\text { Disabled Swarojgaris } \\
\text { Assisted }\end{array}$ & 8529 & 14793 & 31864 & 36113 & 42315 & 23013 \\
\hline 22. & \% age of SC/STs Assisted & 44.32 & 47.65 & 49.75 & 47.83 & 47.04 & 50.47 \\
\hline 23. & $\begin{array}{l}\% \text { age of Minorities } \\
\text { assisted }\end{array}$ & & 3.58 & 8.38 & 14.78 & 11.14 \\
\hline 24. & $\%$ age of Women Assisted & 44.62 & 57.58 & 73.71 & 63.79 & 64.80 & 67.36 \\
\hline 25. & $\begin{array}{l}\% \text { age of Disabled } \\
\text { Assisted }\end{array}$ & 1.29 & 1.88 & 2.13 & 2.27 & 1.98 \\
\hline
\end{tabular}

Source: GOI, Ministry of Rural Development, Annual Report 2009-10.

1) Although table is self-explanatory but few important points as observed from the above are:

2) Over a period of time, allocation of fund both by the Central and the State Governments increased.

3) Although allocation of fund was increased but utilization to available funds/ allocation was low as it never touched even 100 percent in any year.

4) The data reveal that per capita investment, which is an important indicator of incremental capital output ratio, increased over a period of time.

5) Credit -subsidy ratio was hovered around 2 over the years indicating more credit was given than subsidy.

6) With the increase number of SHGs and 77 percent women SHGs (of the total SHGs) indicates more and more women members joined in the income generation activities.

7) As per norm, the percentage of SC/ST assisted should be 50 but only in 2009-10 the same was achieved and in other years it less than the target.

8) As per guidelines of SGSY, the percentage of women assisted should be 40 but it always crossed the target which is praiseworthy.

9) The assistance given to minorities and disabled was always short of the target.

\section{Study Area and Methodology}

The study is based on field visit and PRA methodology (earlier used to call Participatory Rural Appraisal, now PRA is used) was used. Again under PRA, Group Discussion tool was exercised where along with SHG members, local villagers, local officials were present so scope of suppressing information was ruled out. The two SHGs are Rohidas Maharaj SHG of Dhawalapuri village, Aurangabad block and Sri Sai SHG of Fardapur village, block Soyegaon of Aurangabad district and study was conducted in the month of March 2019.

The SHGs were part of earlier Swarnajayanthi Gram Swarojgar Yojana (SGSY), a selfemployment scheme sponsored under Ministry of Rural Development, Government of India. In view of this, few lines about SGSY have been already mentioned here for the benefit of readers. So, the study is based on both primary and secondary data.

Before presenting the cases, few lines about PRA collected from the book of "Whose Reality Counts? Putting the first last" by Robert Chambers are presented PRA as a methodology helps interacting with local communities, understanding them and learning from them. 


\section{Importance of PRA}

PRA helps in generating different kind of data, identifying \& mobilizing intended groups for decision making, project design, implementation, monitoring and evaluation. The basics of PRA are:

- Rapport building

- Role reversal

- Unlearn

- Listen \& Learn

- Trust / faith

- Avoid Biases

- Inter Disciplinary

- Times Saving / rapid / but progressive Learning

- Cross checking by people

- Diversity and reality

- Critical self awareness hand over the stick

- Participation

Case 1: Rohidas Maharaj SHG: The SHG was set up in 2007 at Dhawalapuri village of Aurangabad block of Aurangabad district with $10 \mathrm{SC}$ women. One noteworthy point is that when study was carried out in March 2019, the SHG was 12 years old so it is a sustainable case and set up when Swarnajayanthi Gram Swarojgar Yojana (SGSY) was in operation. Regarding education of the members, the study reveals all the members did not have school education except one who studied up to $7^{\text {th }}$ standard. Of course, other nine members can sign. The SHG was provided cash credit limit (CCL) of Rs.15,000.00 and Rs.10,000.00 under SGSY. It is pertinent to mention that every SHG which was in existence at least for a period of six months and which demonstrated the potential of viable group was provided a revolving fund (one time assistance given by the Government through District Rural Development Agency, DRDA) and cash credit limit (CCL) from the bank which was a sort of loan. Later on, the SHG was extended an amount of Rs.1.90 lakh as loan and Rs.60,000.00 subsidy as per SGSY.

During the course of study, the members informed that they repaid bank loan. The SHG members were involved with making girls/ ladies cloth-wears known as 'top' similar to 'salwar' where embroidery is done for gorgeous looking. The activities were carried out near Aurangabad city in a rented building as it facilitates for marketing as well as raw materials which come from New Delhi can be stored easily. The members come from their village located nearby and after the work goes back.

With the funds received as loan and subsidy, the SHG purchased five embroidery machines, two tailoring machines, one cutting machine and one over-locking machine which are required for making the cloth wears. Further the SHG employed one master craftsman at the wage of Rs. $15,000.00$ and one helper Rs. 7000.00 per month basis. The other women members based on their work are paid- stitching, embroidery etc. When contacted Mrs. Sunita Rohidas Chandra (30 years / $7^{\text {th }}$ pass), Mrs. Hirabai Harichandra (50/ illiterate) and Mrs. Tarabai Chhotturam Bhogure (50 years/illiterate) informed that monthly income of each was hovering around Rs. 10,000.00 
which was in addition to husband's income so each of them could manage the family satisfactorily. According to them, other SHG members were also earning almost the same amount.

Case 2: Sri Sai SHG was established at Fardapur, block Soyegaon in the year 2010 with 10 persons -6 women and 4 men as that time under Swarnajayanti Gram Swarojgar Yojana (SGSY) SHGs could be formed with male and female persons even with only male persons SHG could be formed under SGSY but now under DAY-NRLM only women SHGs can be formed. However, the Sri Sai SHG was extended a sum of Rs.10,000.00 as revolving fund and no other money was extended to the SHG. The another source of raising fund was saving of each member and each was saving @ Rs.100 per month and thus the SHG had substantial corpus fund. While carrying out Group Discussion under PRA, it was observed that each member borrowed loan 2-3 times from SHG's corpus fund (saving plus revolving fund) ranging from Rs.5,000 to Rs.20,000.

The members were involved in different activities like one was making statue etc, by carving stones. The products are sold at shops in Ajanta and other places and during tourists' season he could do brisk business. While interacted with Sri Ankush Yadhav (38 years/ $10^{\text {th }}$ pass) informed that his earning per month on average was Rs.20,000.00. He borrowed loan from SHG's corpus fund four times @ Rs.10,000.00 each time. The other members whom the author interacted were involved in agriculture and allied activities. Mrs. Indubai (widow/ 50 years/ $2^{\text {nd }}$ pass) with four acres of agricultural land and one buffalo was managing families with great economic hardship once upon a time as she had four children- two daughters and two sons. Later on, all married and she got relief. She with bliss also informed that sons were staying with her so she never felt loneliness and one son was earning by carving stone items.

She borrowed from SHG's corpus fund two times Rs.20,000.00 and Rs.10,000.00. The third member interviewed was Mrs. Sangethabai Balunde (35 years/10th pass/2 children). With four acres of agricultural land managing the families without much hassle as husband was working in a private sector. For her agricultural development, she borrowed five times - Rs. 6,000.00 (2 times), Rs. 5,000.00 (2 times) and Rs.10.000.00 (1 time). The fourth member whom the author interacted was $M r$. Krishna (43 years $/ 3^{\text {rd }}$ pass $/ 4$ children). He informed that he borrowed four times from corpus fund of SHG totaling to the tune of Rs. 50,000.00. In addition to agricultural development (having 3 acres of land), he purchased one buffalo, one cow and two plough bullocks.

It is pertinent to mention here that except Sri Ankush Yadhav all the members were earning through agriculture and allied activities so it is not easy to calculate earning of the member, even then at attempt was made to get an idea about the same. And rough calculation reveals that income of each (out of three members) was in the range of Rs. 15,000.00 to Rs20,000.00 per month.

\section{Conclusion}

This field-based study glaringly portrays that by forming SHG, members have been greatly benefitted as whenever required they borrowed from the SHG's corpus fund and both SHGs were functioning for a long time i.e. sustainable one. Even one SHG was functioning with male and female members for last nine years without any hassle. It was also observed that no one was fallen in 'Debt Trap' as members meticulously managing the SHG's corpus fund for many years. 
Therefore, it is suggested that for economic development of the rural families SHG approach is one of the best strategies.

\section{References}

[1] https://aajeevika.gov.in/content/welcome-deendayal-antyodaya-yojana-nrlm/1st April 2019

[2] Robert Chambers, "Whose Reality Counts? Putting the first last" Intermediate Technology Publications, London, 1997.

[3] Ministry of Rural Development, “Annual Report 2009-10”, Government of India.

*Corresponding author.

E-mail address: shankarjagu@ gmail.com 